\title{
Comparison of Urinary Growth Hormone and IGF-I Excretion in Small- and Appropriate-for- Gestational-Age Infants and Healthy Children ${ }^{1}$
}

\author{
TERESA QUATTRIN, CHRISTINE H. ALBINI, BARBARA J. MILLS, AND \\ MARGARET H. MACGILLIVRAY \\ Department of Pediatrics, School of Medicine at State University of New York at Buffalo, \\ Buffalo, New York 14222
}

\begin{abstract}
The output of urinary growth hormone (GH) and IGF-I were quantitated by RIA in 12-h urine collections obtained from infants who were preterm, small for gestational age (PT-SGA, $n=13$ ); preterm, appropriate for gestational age (PT-AGA, $\boldsymbol{n}=27$ ); full term, small for gestational age (FT-SGA, $n=13$ ); and full term, appropriate for gestational age (FT-AGA, $n=29$ ); and from normal children $(n=33)$. The amounts of GH and IGF-I (mean \pm SEM) excreted by the PT-SGA and FT-SGA infants were not significantly lower than those excreted by the PT-AGA and FT-AGA groups, respectively [GH $(\mu \mathrm{g} /$ $\mathrm{kg}$ ): PT-SGA $13.7 \pm 3.1$ versus PT-AGA $14.0 \pm 2.2$, FTSGA $7.8 \pm 2.4$ versus FT-AGA $6.6 \pm 1.8$; IGF-I (nmol/ $\mathrm{kg}$ ): PT-SGA $0.52 \pm 0.09$ versus PT-AGA $0.53 \pm 0.04$, FT-SGA $0.31 \pm 0.05$ versus FT-AGA $0.35 \pm 0.04]$. All infant groups exhibited significantly greater outputs of urinary GH and IGF-I compared with the children $(p<$ 0.01 ). The plasma concentrations of $\mathrm{GH}$ in all infant groups were high, whereas the plasma IGF-I levels were low. Microalbumin and $\beta-2$ microglobulin excretion did not correlate with urinary GH and IGF-I output. Despite the higher microalbumin output in FT babies, urinary GH and IGF-I excretion was lower in these groups. The high plasma and urinary GH levels in the presence of increased urinary IGF-I output suggest that production of these peptides in early life is increased and they may reflect the hormonal mechanisms controlling the rapid somatic growth observed in early infancy. However, we cannot rule out the possibility that urinary IGF-I output is a reflection of renal IGF-I synthesis rather than generalized IGF-I production. Based on the comparison of urinary GH and IGF-I excretion in SGA and AGA infants, it appears that postnatal production of these peptides in SGA infants is not impaired. (Pediatr Res 28: 209-212, 1990)
\end{abstract}

\section{Abbreviations}

GH, growth hormone

SGA, small for gestational age

AGA, appropriate for gestational age

PT, preterm

FT, full term

Received February 23, 1990; accepted May 1, 1990.

Correspondence and reprint requests: Teresa Quattrin, M.D., Children's Hospital of Buffalo, Division of Endocrinology, 219 Bryant Street, Buffalo, NY 14222

Supported in part by the Children's Growth Foundation of Buffalo, New York

1 Presented in part as a poster at the Endocrine Society, New Orleans, LA, June $8-11,1988$
The influences of GH and IGF-I on somatic growth are well established in childhood but less clearly defined during intrauterine life and early infancy. Because many fetal tissues produce abundant amounts of IGF-I in vitro and cord plasma IGF-I levels correlate positively with birth weight and length, IGF-I is assumed to be a stimulus of fetal growth although plasma levels of the peptide are extremely low before birth $(1,2)$. In contrast, $\mathrm{GH}$ is not believed to be essential for somatic growth during intrauterine life, inasmuch as anencephalic fetuses are born with normal length (3).

In a previous study, we reported that urinary excretion of $\mathrm{GH}$ and IGF-I are significantly greater in PT and FT infants than in normal children. We also observed that the outputs of $\mathrm{GH}$ and IGF-I were high in urine and correlated positively, whereas in plasma, GH concentrations were elevated and IGF-I levels were paradoxically low (4). Our findings suggest that measurements of these hormones in urine provide a more accurate assessment of their production and physiologic relationship.

The low somatomedin activity observed in the cord serum of SGA infants compared to control PT and FT infants raises the possibility that the growth retardation seen in the SGA infants may result from an IGF-I deficiency $(5,6)$. The aim of our study, therefore, was to compare the urinary output of GH and IGF-I in SGA-PT and -FT infants with the output of these peptides in PT and FT babies who were AGA. We also compared the output of these peptides in the four infant groups with that observed in healthy children. Lastly, we assessed the output of $\beta-2$ microglobulin and microalbumin as possible indicators of renal maturity.

\section{MATERIALS AND METHODS}

The study population included 40 PT infants, 42 FT infants, and 33 normal children (mean ht $0.9 \pm 0.2 \mathrm{SD}$ units, age 3-17 y). Of the 40 preterm infants, 13 were SGA (group 1; PT-SGA) and 27 were AGA (group 2; PT-AGA). Among the FT infants, 13 were SGA (group 3; FT-SGA) and 29 were AGA (group 4; FT-AGA). Group 5 consisted of healthy children ages 3 to $17 \mathrm{y}$. Demographic data are presented in Table 1. All parents gave written informed consent for their child's participation. Prenatal history was positive for placental pathologies (abruptio placenta, placenta previa, oligohydraminos, etc.) in six PT-SGA infants, preeclampsia/eclampsia in three PT-SGA and three FT-SGA infants, smoking in eight PT-SGA and eight FT-SGA infants, and alcohol abuse in one PT-SGA and one FT-SGA infant. None of the infants' prenatal histories were positive for maternal drug use or diabetes mellitus. There was no clinical or laboratory evidence of intrauterine infection.

In the 33 normal children (group 5), urine samples were collected under parental supervision at home during a 12-h overnight period $(2000-0800 \mathrm{~h})$. In the infants, urine samples 
were collected for a 12 -h period during either the day or night by means of a U-plastic bag, which was emptied periodically by the nursing staff. All diapers were weighed to validate the completeness of the collection. If a sample was contaminated by stool, the previous urines were discarded, and the collection process was restarted. The urine samples were refrigerated at $4^{\circ} \mathrm{C}$ throughout the collection period. Each urine sample was centrifuged to remove particulate matter, and either dialyzed immediately or stored at $-20^{\circ} \mathrm{C}$ for later dialysis. A $50-\mathrm{mL}$ aliquot of urine from each child was dialyzed against redistilled water for $36 \mathrm{~h}$ using 18-mm Spectropor membranes (mol wt cut-off, 3500; Spectrum Industries, Los Angeles, CA), lyophilized in a Virtis Lyophilizer (Virtis Co., Gardiner, NJ), and reconstituted in 1 $\mathrm{mL} 0.04 \mathrm{~mol} / \mathrm{L}$ phosphate buffer, $\mathrm{pH} 7.4$, containing $0.5 \%$ purified human serum albumin (Albuminar-25, Armour Pharmaceutical Co., Kankakee, IL) and $0.9 \%$ sodium chloride. Due to the higher GH and IGF-I excretion in the infants, $25 \mathrm{~mL}$ of their urine were dialyzed and the lyophilizate was reconstituted in $1 \mathrm{~mL}$ (giving a 25 -fold concentration).

Urinary $\mathrm{GH}$ was measured in duplicate by a standard double antibody RIA method using a polyclonal GH antibody and GH standards obtained from the National Hormone and Pituitary Program. The intra- and interassay coefficients of variation were 2.1 and $4.0 \%$, respectively. The sensitivity of the assay was 0.15 $\mu \mathrm{g} / \mathrm{L}$.

Urinary IGF-I was measured in duplicate by RIA using kits purchased from Nichols Institute Diagnostics (San Juan Capistrano, CA). The sensitivity of the assay was $7 \mathrm{mU} / \mathrm{mL}$. The intra- and interassay coefficients of variation were 5.7 and $8.6 \%$, respectively. Plasma GH and IGF-I were measured by these RIA in the infants (groups 1-4). Recovery studies were previously described (4). Urinary creatinine concentrations were measured in samples from $30 \mathrm{PT}, 33 \mathrm{FT}$ infants, and all 33 normal children.

Urinary microalbumin and $\beta-2$ microglobulin in duplicate were measured in samples from $25 \mathrm{PT}$ and 32 FT infants. Microalbumin was measured by a RIA kit purchased from Diagnostic Products Corp. (Los Angeles, CA) and $\beta-2$ microglobulin was quantitated with a RIA kit from Pharmacia, Inc. (Piscataway, NJ). The data, expressed as mean \pm SEM, were standardized for body weight and mol creatinine. The data analysis

Table 1. Clinical and demographic data of study population

\begin{tabular}{cccccc} 
& & & \multicolumn{2}{c}{ At time of study } & \\
\cline { 3 - 5 } Study & & Sex & & $\begin{array}{c}\text { Corrected } \\
\text { gestational }\end{array}$ & Birth wt \\
group & $n$ & $(\mathrm{M} / \mathrm{F})$ & Days of life & age (wk) & $(\mathrm{kg})$ \\
\hline 1 PT-SGA & 13 & $6 / 7$ & $10.4 \pm 2.3$ & $36.5 \pm 0.5$ & $1.6 \pm 0.1$ \\
2 PT-AGA & 27 & $13 / 14$ & $37.0 \pm 6.4$ & $36.0 \pm 0.4$ & $1.6 \pm 0.1$ \\
3 FT-SGA & 13 & $8 / 5$ & $4.4 \pm 1.1$ & & $2.2 \pm 0.1$ \\
4 FT-AGA & 29 & $15 / 14$ & $1.5 \pm 0.1$ & & $3.3 \pm 0.1$ \\
5 Children & 33 & $19 / 14$ & $3-17 \mathrm{y}$ & & \\
\hline
\end{tabular}

Table 2. Urinary growth hormone excretion standardized for body wt and mol creatinine

\begin{tabular}{lcrcc}
\hline Study group & $\mu \mathrm{g} / \mathrm{kg}^{*}$ & $n$ & $\begin{array}{c}\text { Creatinine } \\
(\mu \mathrm{g} / \mathrm{mol}) \dagger\end{array}$ & $n$ \\
\hline 1 PT-SGA & $13.7 \pm 3.1$ & 9 & $200.7 \pm 40.5$ & 12 \\
2 PT-AGA & $14.0 \pm 2.2$ & 27 & $358.4 \pm 90.4$ & 18 \\
3 FT-SGA & $7.8 \pm 2.4$ & 11 & $143.2 \pm 34.9$ & 12 \\
4 FT-AGA & $6.6 \pm 1.8$ & 24 & $132.2 \pm 34.9$ & 21 \\
5 Children & $0.3 \pm 0.02$ & 32 & $4.8 \pm 0.8$ & 32 \\
\hline
\end{tabular}

* Group 5 vs 1, 2, 3, and 4: $p<0.001$; group 1 vs $4: p<0.01$; group 2 vs $4: p<0.001$.

+ Group 5 vs 1, 2, 3, and 4: $p<0.001$; group 1 vs 4: $p<0.05$; group 2 vs 3 and $4: p<0.001$.
Table 3. Urinary IGF-I excretion standardized for body wt and mol creatinine

\begin{tabular}{lcccc}
\hline Study group & nmol/kg* & $n$ & $\begin{array}{c}\text { Creatinine } \\
(\mathrm{nmol} / \mathrm{mol}) \dagger\end{array}$ & $n$ \\
\hline 1 PT-SGA & $0.52 \pm 0.09$ & 10 & $9.0 \pm 1.5$ & 13 \\
2 PT-AGA & $0.53 \pm 0.04$ & 25 & $12.1 \pm 1.6$ & 16 \\
3 FT-SGA & $0.31 \pm 0.05$ & 11 & $6.0 \pm 0.9$ & 12 \\
4 FT-AGA & $0.35 \pm 0.04$ & 24 & $5.5 \pm 1.0$ & 21 \\
5 Children & $0.15 \pm 0.01$ & 32 & $2.4 \pm 0.2$ & 32 \\
\hline
\end{tabular}

* Group 5 vs 1, 2, 3, and 4: $p<0.001$; group 2 vs 3: $p<0.001$; group 2 vs $4: p<0.001$.

$\dagger$ Group 5 vs 1, 2, 3, and 4: $p<0.001$; group 1 vs 4: $p<0.05$; group 2 vs 3 and 4: $p<0.001$.

Table 4. Plasma growth hormone and IGF-I

\begin{tabular}{lcccc}
\hline Study group & $\begin{array}{c}\text { Plasma GH* } \\
(\mu \mathrm{g} / \mathrm{mL})\end{array}$ & $n$ & $\begin{array}{c}\text { Plasma IGF-I } \\
(\mathrm{nmol} / \mathrm{L})\end{array}$ & $n$ \\
\hline 1 PT-SGA & $32.1 \pm 6.3$ & 7 & $1.5 \pm 0.2$ & 8 \\
2 PT-AGA & $17.4 \pm 3.3$ & 9 & $2.5 \pm 0.4$ & 9 \\
3 FT-SGA & $36.6 \pm 4.8$ & 7 & $1.8 \pm 0.6$ & 6 \\
4 FT-AGA & $28.8 \pm 7.9$ & 8 & $1.6 \pm 0.2$ & 8 \\
\hline
\end{tabular}

* Group 2 vs 3: $p<0.001$.

Table 5. Urinary microalbumin and $\beta-2$ microglobulin

\begin{tabular}{lcrcr}
\hline Study group & $\begin{array}{c}\text { Microalbumin } \\
(\mu \mathrm{g} / \mathrm{mL})^{*}\end{array}$ & $n$ & $\begin{array}{c}\beta-2 \text { microglobulin } \\
(\mathrm{mg} / \mathrm{L}) \dagger\end{array}$ & $n$ \\
\hline 1 PT-SGA & $11.8 \pm 3.1$ & 10 & $3.6 \pm 1.0$ & 10 \\
2 PT-AGA & $10.8 \pm 2.0$ & 15 & $4.2 \pm 1.1$ & 15 \\
3 FT-SGA & $26.1 \pm 11.6$ & 9 & $3.6 \pm 1.6$ & 9 \\
4 FT-AGA & $41.2 \pm 7.4$ & 23 & $1.8 \pm 0.5$ & 23 \\
\hline
\end{tabular}

* Groups 1 and 2 vs 4: $p<0.01$.

$\dagger$ Groups 1 and 3 vs 4: $p<0.05$; group 2 vs 4: $p<0.01$.

was performed according to the statistical package for the social sciences (SPSS/PC+) using the Mann-Whitney U test.

\section{RESULTS}

Urinary GH and IGF-I excretion in the groups of SGA and AGA PT and FT infants and in the children are shown in Tables 2 and 3 . All the infant groups (groups 1-4) exhibited significantly greater output of urinary GH and IGF-I than the children $(p<$ 0.001 ) (Table 2). The amounts of GH and IGF-I excreted by the PT-SGA and FT-SGA infants were not significantly lower than those excreted by the PT-AGA and FT-AGA groups [GH $(\mu \mathrm{g} /$ $\mathrm{kg}$ ): PT-SGA $13.7 \pm 3.1$ versus PT-AGA $14.0 \pm 2.2$, FT-SGA $7.8 \pm 2.4$ versus FT-AGA $6.6 \pm 1.8$; IGF-I $(\mathrm{nmol} / \mathrm{kg}):$ PT-SGA $0.52 \pm 0.09$ versus $\mathrm{PT}$-AGA $0.53 \pm 0.04$, FT-SGA $0.31 \pm 0.05$ versus FT-AGA $0.35 \pm 0.04$ ] (Tables 2 and 3). Significantly higher amounts of urinary GH and IGF-I were excreted by the PT-AGA infants compared with the FT-AGA infants [GH $(\mu \mathrm{g} /$ $\mathrm{kg}): 14.0 \pm 2.2$ versus $6.6 \pm 1.8, p<0.05$; IGF-I $(\mathrm{nmol} / \mathrm{kg}): 0.53$ \pm 0.04 versus $0.35 \pm 0.04, p<0.05$ ] (Table 3 ). Although the output of these peptides in the PT-SGA infants was higher than in the FT-SGA infants, the differences did not reach statistical significance. However, when all PT infants (groups 1 and 2) were compared with all FT babies (groups 3 and 4), the PT babies excreted significantly greater amounts of GH than the FT infants $(p<0.05)$.

Analysis of urinary GH and IGF-I excretion based on creatinine output $(\mathrm{GH}, \mu \mathrm{g} / \mathrm{mol}$ creatinine and IGF-I, nmol/mol creatinine) yielded results that were comparable to those based on body weight in that no statistical differences were observed in the urinary output of GH and IGF-I between the SGA and AGA populations (Tables 2 and 3). In fact, similar to the observation 
reported above, PT-AGA infants excreted significantly higher amounts of GH and IGF-I per mol creatinine compared with the FT-AGA and FT-SGA babies. Among the entire study populations (groups 1 to 5), urinary GH and IGF-I excretion correlated positively $(r=0.56, p<0.01)$. A positive significant correlation was present also when considering the infant groups separately $(r=0.53, p<0.01)$.

Plasma GH concentrations obtained randomly during the collection of urine specimens were high in all infant groups. The plasma GH levels in the PT-SGA $(32.1 \pm 6.3 \mu \mathrm{g} / \mathrm{L})$ and FTSGA $(36.6 \pm 4.8 \mu \mathrm{g} / \mathrm{L})$ infants were higher than the mean values observed in PT-AGA infants $(17.4 \pm 3.3 \mu \mathrm{g} / \mathrm{L})$, but reached statistical significance only in the comparison of group 2 with group $3(p<0.001)$. The plasma IGF-I $(\mathrm{nmol} / \mathrm{L})$ levels did not differ significantly within the four infant groups (PT-SGA $1.5 \pm$ 0.2 , PT-AGA $2.5 \pm 0.4$, FT-SGA $1.8 \pm 0.6$, and FT-AGA $1.6 \pm$ 0.2 ) (Table 4).

Urinary microalbumin excretion in the FT-AGA infants $(41.2$ $\pm 7.4 \mathrm{mg} / \mathrm{mL}$ ) was significantly higher than in the SGA and AGA PT groups $(11.8 \pm 3.1$ and $10.8 \pm 2.0 \mathrm{mg} / \mathrm{mL}$, respectively, $p<0.01)$. The FT-AGA infants were studied on the 2 nd day of life, at a younger age than the infants in the other groups. $\beta-2$ microglobulin excretion was significantly lower in FT-AGA infants $(1.8 \pm 0.5 \mathrm{mg} / \mathrm{L})$ than in any of the other infant groups (PT-SGA $3.6 \pm 1.0$, PT-AGA $4.2 \pm 1.1$, and FT-SGA $3.6 \pm 1.6$ $\mathrm{mg} / \mathrm{L}$ ) (Table 5).

\section{DISCUSSION}

Our study suggests that postnatal production of GH and IGFI in PT-SGA and FT-SGA infants is not impaired. The conclusion is based on the observations of similar urinary outputs of GH and IGF-I in PT-SGA and FT-SGA infants compared with PT-AGA and FT-AGA babies, respectively. Also, the plasma levels of these peptides in the SGA groups (groups 1 and 3) were comparable to or higher than the concentrations observed in the two groups of AGA babies (groups 2 and 4). The low levels of plasma IGF-I reported previously in SGA infants at birth and at $5 \mathrm{~d}$ of age contrast with our findings and may be explained by the difference in the ages of the study populations and the assay methodologies (7). Our study does not address production of these peptides prenatally.

The influence of renal function on the measurements of urinary GH and IGF-I output in infants are unknown. We observed that PT (SGA and AGA) babies had higher urinary outputs of GH and IGF-I than FT (SGA and AGA) infants, but the differences reached significance only with the PT-AGA versus the FTAGA groups. It is unlikely that the higher output of urinary $\mathrm{GH}$ observed in PT versus FT infants is due solely to renal immaturity, inasmuch as plasma levels of $\mathrm{GH}$ were high in all infant groups, suggesting that augmented $\mathrm{GH}$ production is a major reason for the high urinary output of $\mathrm{GH}$ in early life. In FTAGA infants, urinary microalbumin measurements were significantly higher than those observed in the other groups. This result is probably due to the younger age of these infants, inasmuch as transient proteinuria is known to occur during the first 3 to $5 \mathrm{~d}$ of life (8). Despite the higher microalbumin output in FT babies, urinary GH and IGF-I excretion was lower in FT than in PT groups. Karlsson et al. (9) reported that urinary $\beta-2$ microglobulin levels were low at birth, peaked at $5 \mathrm{~d}$ of life, remained elevated during the 1 st mo of life, and declined gradually thereafter (9). Similarly, in our study, the $\beta-2$ microglobulin measurements were significantly lower in the FT-AGA infants (group 4), whose mean age at the time of study was only $1.5 \pm$ $0.1 \mathrm{~d}$, compared with the mean age range of 4.4 to $37 \mathrm{~d}$ in the other infant groups. Because the corrected gestational age in our PT population was close to FT, differences in tubular maturation should not have played a major role (8). In our infant populations, we did not observe a direct correlation between urinary $\beta$ -
2 microglobulin and urinary GH excretion, although a positive relationship has been reported in adults with renal disease (10). Because urinary GH output in FT-SGA and FT-AGA babies was similar, although $\beta-2$ microglobulin was higher in the former group, it appears that $\beta-2$ microglobulin measurements cannot be used to assess renal tubular handling of $\mathrm{GH}$ in infants.

Standardization of urinary hormone measurements per mol of urinary creatinine has inherent problems because the neonatal serum creatinine level reflects that of the mother, with a rapid decrease in FT and a slower decrease in PT during the 1st wk of life (11-14). Nevertheless, expression of the data based on urinary creatinine or body weight yielded similar interpretations.

The origin of urinary IGF-I has not been clarified. Previous studies have shown that this peptide in urine is authentic based on HPLC and linearity evaluations (4). Also, we have previously shown that urinary IGF-I is GH-dependent, since low output in hypopituitary children is promptly corrected after $\mathrm{GH}$ administration $(15)$. Whether the peptide originates exclusively in the renal parenchyma or is partly derived from circulating IGF-I remains unclear $(16,17)$. Plasma IGF-I levels are low in infants, whereas output in urine is very high; therefore, we hypothesize that urinary IGF-I is most likely derived from renal tissue. This conclusion is supported by evidence documenting greater renal synthesis of IGF-I in young compared with mature organs (18). We previously reported a positive correlation between this peptide and $\mathrm{GH}$ in urine of normally growing PT and FT babies and suggested that this noninvasive method would yield information about the role of this peptide in other populations. Our current study, using this approach, indicates that in SGA infants the postnatal production of GH and IGF-I is not impaired.

Acknowledgments. The authors thank Deborah Wachowicz for her help with manuscript preparation and our laboratory technicians Irene Johnson and Lisa Phillips.

\section{REFERENCES}

1. Gluckman PD, Brinsmead MW 1976 Somatomedin in cord blood: relationship to gestational age and birth size. J Clin Endocrinol Metab 43:1378-1381

2. Han VK, Hill DJ, Strain AJ, Towle AC, Lauder JM, Underwood LE, D'Ercole AJ 1987 Identification of somatomedin/insulin-like growth factor immunoreactive cells in the human fetus. Pediatr Res 22:245-291

3. Gluckman PD, Grumbach MM, Kaplan SL 1981 The neuroendocrine regulation and function of growth hormone and prolactin in the mammalian fetus. Endocr Rev 2:363-395

4. Quattrin T, Albini CH, Cara JF, Vandlen RL, Mills BJ, MacGillivray MH 1988 Quantitation of urinary somatomedian-C and growth hormone in preterm and fullterm infants and normal children. J Clin Endocrinol Metab 66:792-797

5. Foley TP, DePhilip R, Perricelli A, Miller A 1980 Low somatomedin activity in cord serum from infants with intrauterine growth retardation. J Pediatr 96:605-610

6. Vileisis RA, D'Ercole AJ 1986 Tissue and serum concentrations of somatomedin-C/insulin-like growth factor I in fetal rats made growth retarded by uterine artery ligation. Pediatr Res 20:126-130

7. Thieriot-Prevost G, Boccara JF, Francoual C, Badoual J, Job JC 1988 Serum insulin-like growth factor I and serum growth-promoting activity during the first postnatal year in infants with intrauterine growth retardation. Pediatr Res 24:380-383

8. Guignard JP 1982 Renal function in the newborn infant. Pediatr Clin North Am 29:777-789

9. Karlsson FA, Hardell LI, Kristoffer H 1979 A prospective study of urinary proteins in early infants. Acta Paediatr Scand 68:664-667

10. Hattori N, Kato Y, Murakami Y, Hashida S, Ishikawa E, Mohri Z, Imura H 1988 Urinary growth hormone levels measured by ultrasensitive enzyme immunoassay in patients with renal insufficiency. J Clin Endocrinol Metab 66:727-732

11. Forbes G, Bruining G 1976 Urinary creatinine excretion and lean body mass. Am J Clin Nutr 29:1359-1366

12. Ballard F, Burgoyne J, Thomas F, Penfold JL 1983 Growth hormone induced changes in myofibrillar protein breakdown in hypopituitary children. Clin Sci $64: 315-320$ 
13. Engle WD 1986 Evaluation of renal function and acute renal failure in the neonate. Pediatr Clin North Am 33:129-151

14. Sertel H, Scopes J 1973 Rates of creatinine clearance in babies less than one week of age. Arch Dis Child 48:717-720

15. Quattrin T, Albini CH, Vandien RL, MacGillivray MH 1987 Quantitation of urinary somatomedin- $\mathrm{C}$ in children with normal and abnormal growth. $\mathrm{J}$ Clin Endocrinol Metab 65:1168-1171

16. D'Ercole AJ, Stiles AD, Underwood LE 1984 Tissue concentrations of soma-
tomedin-C: further evidence for multiple sites of synthesis and paracrine or autocrine mechanisms of action. Proc Natl Acad Sci USA 81:935-937

17. D'Ercole AJ, Decedue CJ, Furlanetto RW, Underwood LE, Van Wyk JJ 1977 Evidence that somatomedin-C is degraded by the kidney and inhibits insulin degradation. Endocrinology 101:577-585

18. Han VKM, Hill DJ, Strain AJ, Towle AC, Lauder JM, Underwood LE, D'ercole J 1987 Identification of somatomedin/insulin-like growth factor immunoreactive cells in the human fetus. 22:245-249

\section{Announcements}

\section{9th International Society on Oxygen Transport to Tissue (ISOTT) Meeting \\ Curaçao, Netherlands Antilles, April 8-12, 1991}

For information, contact: Professor W. Erdmann, Dept. of Anesthesiology, Dr. Molewaterplein 40, 3015 GD Rotterdam, The Netherlands. Tel.: 31-10-4633458; FAX: 31-10-4367870.

\section{Conference on Congenital Anomalies}

The Office of Continuing Medical Education of the University of Michigan Medical School is sponsoring a conference entitled "Congenital Anomalies" to be held November 8-9, 1990 at The Towsley Center, University of Michigan, Ann Arbor, Michigan. Participants may receive 15 credit hours in category I of the Physician's Recognition Award of the American Medical Association. The Course Director is Dr. Steven M. Donn, Associate Professor, Department of Pediatrics and Communicable Diseases, Section of Newborn Services, and Medical Director of Holden Neonatal ICU. For further information, contact: Julie Jacobs, Office of Continuing Medical Education, G-1100 Towsley Center, Box 0201, University of Michigan Medical School, Ann Arbor, MI 481090201, (313) 763-1400. 